\title{
31. DIATOM PALEOCEANOGRAPHY AND PALEOCLIMATOLOGY OF THE CENTRAL AND EASTERN EQUATORIAL PACIFIC BETWEEN 18 AND $6.2 \mathrm{Ma}^{1}$
}

\author{
John A. Barron, U.S. Geological Survey, Menlo Park²
}

\begin{abstract}
Diatom assemblages in the central and eastern equatorial Pacific record the effects of polar cooling in the middle Miocene and across the middle/late Miocene boundary. Diatom evolutionary events (appearances and extinctions) were numerous between 14.5 and $13.5 \mathrm{Ma}$, presumably reflecting reorganization of equatorial surface-water masses in response to polar cooling. Increasing numbers of the cold-water diatom Denticulopsis hustedtii indicate cooling of equatorial Pacific surface waters during the middle Miocene, especially between 12 and $11.5 \mathrm{Ma}$. The onset of severe carbonate dissolution at $12 \mathrm{Ma}$ marked the beginning of the late Neogene period of high-amplitude fluctuations of carbonate in the equatorial Pacific. Initiation or a substantial increase in the production of North Atlantic Deep Water (NADW) in the North Atlantic at $12 \mathrm{Ma}$ is believed to have been a possible triggering event for these middle/late Miocene changes. Increased polar cooling at 11.3 Ma contributed to steepening of latitudinal thermal gradients by altering circulation patterns. Tropical surface waters became warmer, cold-water diatoms were excluded from the equatorial Pacific, and latitudinal provincialism was enhanced in all planktonic groups. Most of the modern-day features of equatorial $\mathrm{Pa}$ cific surface-water circulation were probably present by 11 Ma.
\end{abstract}

\section{INTRODUCTION}

A primary purpose of DSDP Leg 85 was to collect a series of upper Eocene to Quaternary reference sections across the region of high productivity of the central equatorial Pacific Ocean. Cores previously collected from the area on DSDP Legs 5, 8, 9, and 16 have provided a wealth of paleoceanographic information (van Andel et al., 1975), but high-resolution biostratigraphic studies have been hindered by the disturbed nature of the rotary-drilled cores and by spotty recovery. Use of the hydraulic piston corer (HPC) on Leg 85 allowed recovery of relatively undisturbed cores in sediments with moderate to high ( $\geq 15 \mathrm{~m} / \mathrm{m}$.y.) sedimentation rates at five locations (Sites 571 to 575 ) across the central equatorial Pacific (Fig. 1).

Sites 571 and 572 lie along the western edge of the highly productive eastern equatorial Pacific, where sediments are dominated by diatoms and the regional thermocline is relatively shallow. Sediment accumulation rates were at least 1.7 times faster at Sites 571 and 572 than the rates at the more carbonate-rich western sites (Sites 573 to 575) (Barron, this volume). Only one uppermost Quaternary core was recovered at Site 571 , but over $400 \mathrm{~m}$ of lower middle Miocene to Quaternary diatom-rich sediments were recovered at Site 572. HPC coring at Site 572 extended down to $172 \mathrm{~m}$ sub-bottom (about 6.1 Ma); rotary coring extended to the base of the hole.

Sites 573 to 575 form a south-to-north transect across the northward-migrating Oligocene to Holocene equator. Upper Eocene to Quaternary sections were recovered at Sites 573 and 574; HPC coring extended down to the lower upper Miocene and upper lower Miocene, re-

\footnotetext{
${ }^{1}$ Mayer, L., Theyer, F., et al., Init. Repts. DSDP, 85: Washington (U.S. Govt. Printing Office).

2 Address: U.S. Geological Survey, 345 Middlefield Rd., Menlo Park, CA 94025.
}

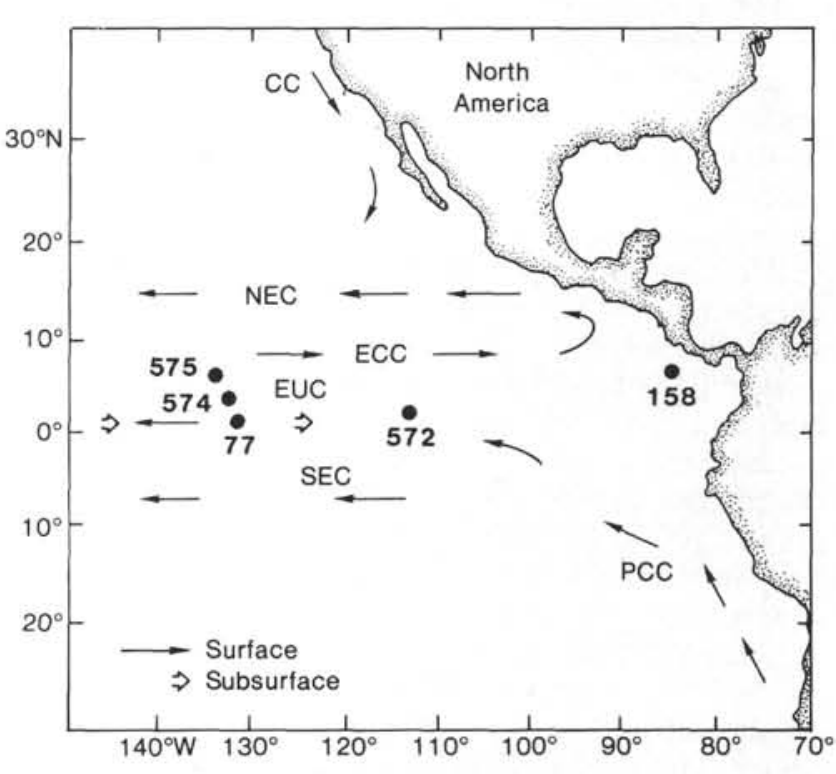

Figure 1. Locations of studied DSDP sites in the central and eastern equatorial Pacific. Surface currents: PCC $=$ Peru-Chile Current, $\mathrm{SEC}=$ South Equatorial Current, ECC $=$ Equatorial Countercurrent, NEC $=$ North Equatorial Current, $\mathrm{CC}=$ California Current. Subsurface current: EUC $=$ Equatorial Undercurrent. Currents after Wyrtki (1966).

spectively. All coring at Site 575 was done with the HPC, and the oldest sediments recovered are about $22 \mathrm{Ma}$ old (Barron, this volume).

The middle and late Miocene were times of maximum diatom abundance in the central equatorial Pacific (van Andel et al., 1975; Leinen, 1979). Major global cooling occurred in the middle Miocene (Shackleton and Kennett, 1975; Woodruff et al., 1981), and modern patterns of surface-water circulation were largely established (van Andel et al., 1975; Keller and Barron, 1983), although circulation of surface waters across the Central 
American Seaway did not cease until the Pliocene. Because diatoms are phytoplankton, they respond to conditions in the photic zone (temperature, salinity, nutrients), and, therefore, they should monitor fluctuations in surface water masses (Kanaya and Koizumi, 1966; Cooke-Poferl et al., 1975). With this in mind, stratigraphic intervals were selected for study between the upper lower Miocene (about $18 \mathrm{Ma}$ ) and the uppermost Miocene (6.2 $\mathrm{Ma}$ ) across the central and eastern equatorial Pacific at DSDP Sites 77, 158, 572, 574, and 575. Planktonic diatoms were counted at sampling intervals representing, on average, 100,000 yrs. in the early and middle Miocene and 200,000 to 300,000 yrs. in the late Miocene. The greater sampling interval for the late Miocene reflects slower sedimentation rates. Results are presented in Barron (this volume), along with quantitative trends (paleogeography) across the central and eastern equatorial Pacific. The purpose of this chapter is to apply those quantitative data in a study of the oceanography and climatology of the interval from 18 to $6.2 \mathrm{Ma}$ in the central and eastern equatorial Pacific.

\section{MIDDLE MIOCENE COOLING}

The $+1.00 \%$ increase in benthic foraminiferal $\delta^{18} \mathrm{O}$ that occurred throughout the ocean basins in the early middle Miocene (Shackleton and Kennett, 1975; Savin et al., 1975; Woodruff et al., 1981; Blanc and Duplessy, 1982 ) is the most distinctive feature of late Cenozoic oxygen-isotope curves. This increase has been interpreted as a response to polar cooling and growth of the Antarctic Ice Cap, although Matthews and Poore (1980) have questioned whether it represented the initiation of Antarctic glaciation.

Benthic and planktonic microfossil assemblages at both high and low latitudes underwent pronounced changes in response to global cooling in the middle Miocene (Keller and Barron, 1983, and references therein). Oligocene and lower Miocene benthic foraminifers in the western Pacific disappeared and were replaced by more characteristic Neogene assemblages at about $13.5 \mathrm{Ma}$, presumably reflecting the increasing amount of Antarctic Bottom Water (AABW) entering the deep Pacific (Woodruff and Douglas, 1981). The number of evolutionary events (first and last appearances) of planktonic microfossils was high during the middle part of the middle Miocene (14.5 to $13.5 \mathrm{Ma}$ ), in response to reorganization of surface and intermediate water masses. Planktonic foraminifers (Blow, 1969; Keller, 1981; Srinivasan and Kennett, 1981), radiolarians (Riedel and Sanfilippo, 1978; Goll, 1979), calcareous nannofossils (Martini, 1971; Bukry, 1978), silicoflagellates (Bukry, 1981a), and diatoms (Burckle, 1978; Barron, 1981a, b) all had numerous appearances and extinctions during that part of the middle Miocene.

The following list shows diatom evolutionary events for the late early Miocene to latest Miocene (18.0 to 5.1 $\mathrm{Ma}$ ) of the equatorial Pacific, as compiled from Tables 1 and 3 of Barron (this volume) for 500,000-yr. intervals; all datum-level ages are rounded off to $100,000 \mathrm{yrs}$., and intervals shown are inclusive.

\begin{tabular}{cc}
\hline Age (Ma) & $\begin{array}{c}\text { Number of } \\
\text { appearances/extinctions }\end{array}$ \\
\hline $5.1-5.5$ & $1 / 3$ \\
$5.6-6.0$ & $0 / 3$ \\
$6.1-6.5$ & $3 / 0$ \\
$6.6-7.0$ & $0 / 1$ \\
$7.1-7.5$ & $1 / 1$ \\
$7.6-8.0$ & $1 / 3$ \\
$8.1-8.5$ & $1 / 0$ \\
$8.6-9.0$ & $2 / 1$ \\
$9.1-9.5$ & $0 / 2$ \\
$9.6-10.0$ & $2 / 1$ \\
$10.1-10.5$ & $2 / 0$ \\
$10.6-11.0$ & $0 / 2$ \\
$11.1-11.5$ & $2 / 1$ \\
$11.6-12.0$ & $0 / 1$ \\
$12.1-12.5$ & $3 / 4$ \\
$12.6-13.0$ & $2 / 1$ \\
$13.1-13.5$ & $1 / 3$ \\
$13.6-14.0$ & $7 / 3$ \\
$14.1-14.5$ & $4 / 2$ \\
$14.6-15.0$ & 0 \\
$15.1-15.5$ & $1 / 1$ \\
$15.6-16.0$ & $0 / 3$ \\
$16.1-16.5$ & $1 / 2$ \\
$16.6-17.0$ & $1 / 1$ \\
$17.1-17.5$ & $6 / 2$ \\
$17.6-18.0$ & $1 / 4$ \\
\hline
\end{tabular}

For the period studied, diatoms average 3.4 first appearances and 3.1 last appearances per million-year interval. Periods of maximum turnover occur between 17.5 and $17.1 \mathrm{Ma}$ (6 appearances and 2 extinctions), 14.5 and 14.1 Ma (4 appearances and 2 extinctions), 14.0 and $13.6 \mathrm{Ma}$ ( 7 appearances and 3 extinctions), and 12.5 and 12.1 Ma (3 appearances and 4 extinctions). The older $(17.5$ to $17.1 \mathrm{Ma})$ and younger $(12.5$ to $12.1 \mathrm{Ma})$ of these times of rapid turnover in diatom taxa precisely match periods of rapid change in planktonic foraminifers (Keller, 1981) and radiolarians (Goll, 1979) at DSDP Site 77 . The middle periods (14.5 to $13.6 \mathrm{Ma}$ ) correspond to that part of the middle Miocene where the $\delta^{18} \mathrm{O}$ of benthic foraminifers shows a $+1.0 \% 0$ increase and all planktonic organisms have high numbers of evolutionary events (Ryan et al., 1974; Barron et al., in press).

\section{PALEOTEMPERATURE CURVES}

\section{Denticulopsis nicobarica (17.8 to 13.6 Ma)}

Figure 2 compares the abundance of Denticulopsis nicobarica at Sites 574 and 575 (Barron, this volume) with the benthic foraminiferal oxygen-isotope curves for Sites 289 (Woodruff et al., 1981) and 574 (Shackleton and Pisias, this volume). The Site 574 isotope curve is simplified from that of Shackleton and Pisias (this volume), in that only isotope values from the same depth intervals as those for which the abundance of $D$. nicobarica was determined are plotted. The overall trend of increasing $D$. nicobarica between 15.5 and $13.6 \mathrm{Ma}$ is mirrored by a greater than $+1.00 \%$ increase in $\delta^{18} \mathrm{O}$ at Site 289. The rapid decline in $D$. nicobarica abundance beginning at $13.5 \mathrm{Ma}$, however, does not represent warming in the isotope curve, but rather corresponds to a time of rapid species turnover in diatoms (see preceding tabulation), and may have been caused by reorganiza- 


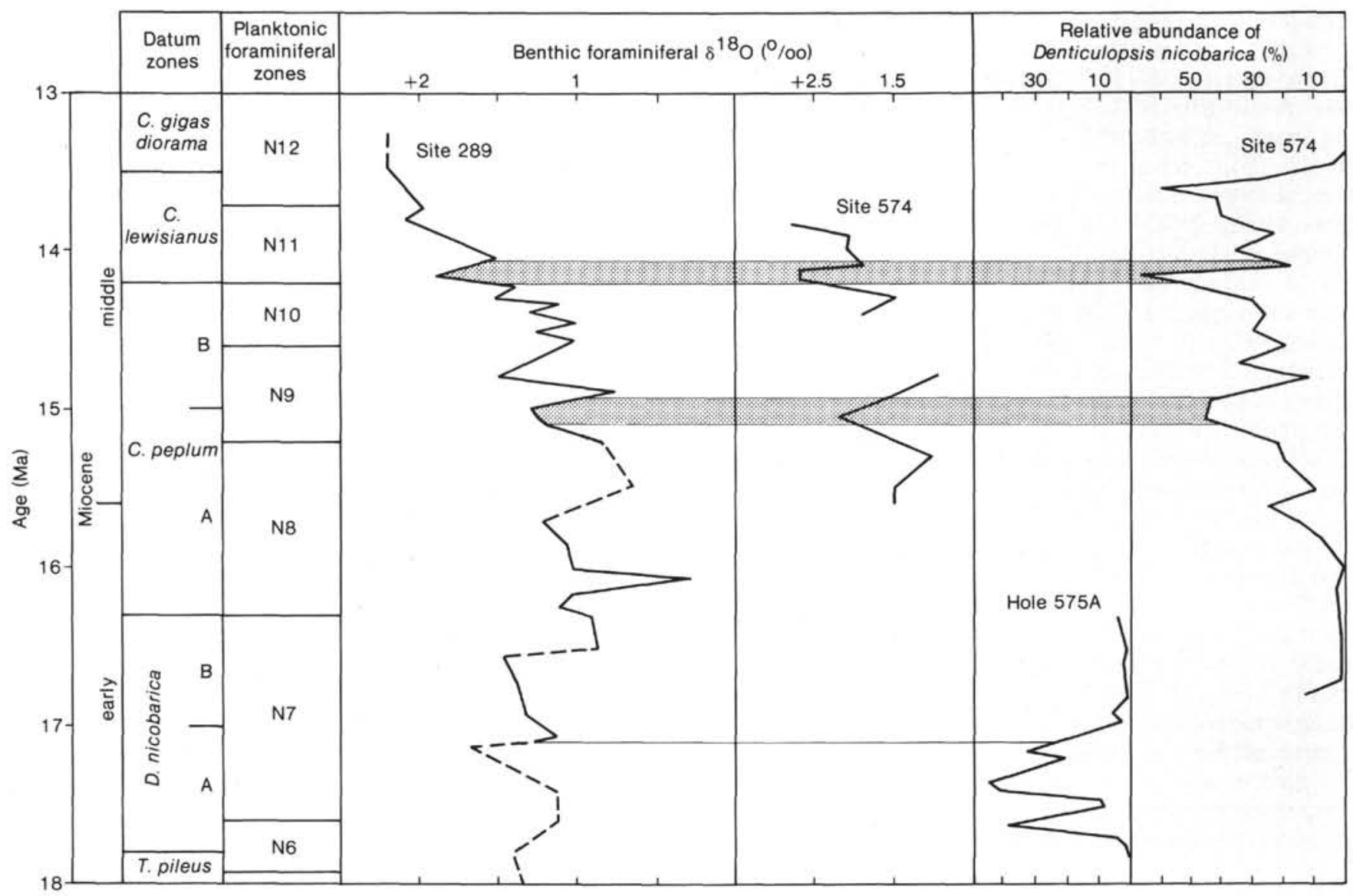

Figure 2. Comparison of the percent of Denticulopsis nicobarica (17.8 to 13.2 Ma) at central equatorial Pacific DSDP Sites 575 (Hole 575A) and 574 (Barron, this volume) with benthic foraminiferal oxygen-isotope curves for Sites 289 (Woodruff et al., 1981) and 574 (Shackleton and Pisias, this volume). The Site 575 isotope curve is constructed only from those points at the same sub-bottom depths as the Site 574 diatom samples. Shaded area emphasizes correlation between abundant $D$. nicobarica and more positive $\delta^{18} \mathrm{O}(\%)$ values.

tion of equatorial Pacific water masses (Woodruff and Douglas, 1981). Individual spikes in the curves from 15.1 to $14.9,14.2$ to 14.1 , and $13.6 \mathrm{Ma}$ are strongly correlative. The increasing abundance of $D$. nicobarica between 17.6 and $17.1 \mathrm{Ma}$ (Site 575) correlates closely with a cooling in the silicoflagellate paleotemperature curve Bukry (this volume), and is equivalent to the interval removed by hiatus NH1b at Site 573 (Barron, this volume). The relatively wide spacing of isotope values in the isotope curve below $16.5 \mathrm{Ma}$ hinders effective comparison with the $D$. nicobarica curve. Lower oxygen-isotope values $(+1.0 \%$ ) between 17 and $15 \mathrm{Ma}$, however, generally correspond to minimal values $(10 \%)$ of $D$. $n i$ cobarica. In this interval of lower $D$. nicobarica values, the warm-water diatoms Cestodiscus pulchellus and Synedra jouseana are relatively common (Barron, this volume). It thus appears that the relative abundance of $D$. nicobarica between its first appearance at $17.8 \mathrm{Ma}$ and its decline at $13.5 \mathrm{Ma}$ in the central equatorial Pacific varies positively with polar cooling, as measured by oxygen isotopes.

Comparison of the D. nicobarica abundance curves for central equatorial Pacific Sites 574 and 77 with that for eastern equatorial Pacific Site 572 between 14.4 and 13.5 Ma (Barron, this volume) shows an eastern abun- dance preference of $D$. nicobarica of 10 to $20 \%$. This would be expected if increases of $D$. nicobarica at Sites 77 and 574 represent expansion of $D$. nicobarica westward from the cooler eastern equatorial Pacific during times of polar cooling.

\section{Thalassionema nitzschioides}

Studies of the latest Quaternary by CLIMAP (1976) indicate that the central equatorial Pacific is an excellent place to investigate paleotemperature changes associated with expanded polar glaciation. During the last glacial maximum 18,000 yrs. ago, sea-surface temperatures in the central equatorial Pacific were as much as $6^{\circ} \mathrm{C} \mathrm{cool-}$ er than present-day August temperatures there; this represents a maximum cooling for the low-latitude ocean. Presumably, this cooling resulted from increased upwelling along the equatorial divergences caused by a more energetic circulation system (CLIMAP, 1976). Pedersen (1983) argues that a pronounced enrichment in the organic-carbon content of eastern equatorial Pacific sediments during the last glacial maximum suggests increased productivity rates and supports other evidence that global trade-wind speeds (and thus upwelling rates) increase significantly during glacial stages. Romine (1982) shows that during the last glacial maximum, radiolarian as- 


\section{J. A. BARRON}

semblages associated with the Peru-Chile Current expanded westward into the central equatorial Pacific. Cooke-Poferl et al. (1975) suggest that the diatoms Thalassionema nitzschioides and T. nitzschioides var. parva are associated with the Peru-Chile Current, and Burckle et al. (1982) argue that the increasing abundance of these diatoms in the early late Miocene at eastern equatorial Pacific DSDP Site 158 reflected an increasing influence of the Peru-Chile Current in the area. Barron (1982) used similar arguments, linking $T$. nitzschioides with subtropical and equatorial upwelling (Bukry and Foster, 1973; Sancetta, 1983; Barron and Keller, 1983), to suggest that increased abundance of $T$. nitzschioides at central equatorial Pacific DSDP Site 77 coincided with late middle Miocene and late Miocene periods of middle-latitude cooling identified by Barron and Keller (1983) for the northeastern Pacific.

On Figure 3, the percentage of Thalassionema nitzschioides at central equatorial Pacific DSDP Sites 572 and 574 (Barron, this volume) is plotted along with the benthic foraminiferal oxygen-isotope curves for DSDP Sites 289 (Woodruff et al., 1981), 158 (Keigwin, 1979), and 574 (Shackleton and Pisias, this volume), for the middle Miocene interval from 16.0 to $10.5 \mathrm{Ma}$. Correlations with isotope curves for the late Miocene were not attempted, because detailed sampling is lacking in both the diatom abundance and isotope curves. Conversion of the isotope curve for Site 289 to Ma follows Barron et al. (in press) and utilizes the same time scale as this chap- ter. Ages for the Site 158 curve are after Barron (this volume). The $+1.00 \%$ increase in the Site 289 isotope curve between 14.5 and $13.5 \mathrm{Ma}$ is immediately apparent, and roughly coincides with a general increase in $T$. nitzschioides abundance at both Site 574 (from about $10 \%$ to about $30 \%$ ) and Site 572 (from about $15 \%$ to about $30 \%$ ). In addition, the $+0.5 \%$ increase in the Site 158 isotope curve at about $11.3 \mathrm{Ma}$ corresponds to further increases in T. nitzschioides abundance at both Site 574 (from $25-35 \%$ to $45-55 \%$ ) and Site 572 (from $30-40 \%$ to $60+\%)$. This latter increase is the one identified by Burckle et al. (1982) at Site 158. Point-for-point comparison between the various curves reveals that $T$. nitzschioides values are typically at least $10 \%$ greater at eastern Site 572 than at western Site 574 after 14.2 Ma. This is to be expected, since Site 572 lies within the cooler, more diatom-rich eastern equatorial Pacific and is closer to the northwest fringes of the Peru-Chile Current. Not only do the overall trends in the oxygen-isotope curve appear to correlate with the overall abundance trends of T. nitzschioides, but individual peaks in T. nitzschioides abundance appear to correlate with positive peaks in the oxygen-isotope curves. Admittedly, this correlation is tenuous because of the limits of correlation and the general high variability of both curves. Paired samples should be studied for isotopes and diatom abundance to establish such a relationship. The isotope curve plotted for Site 574 does, however, consist only of points measured on samples from the same depths as the dia-

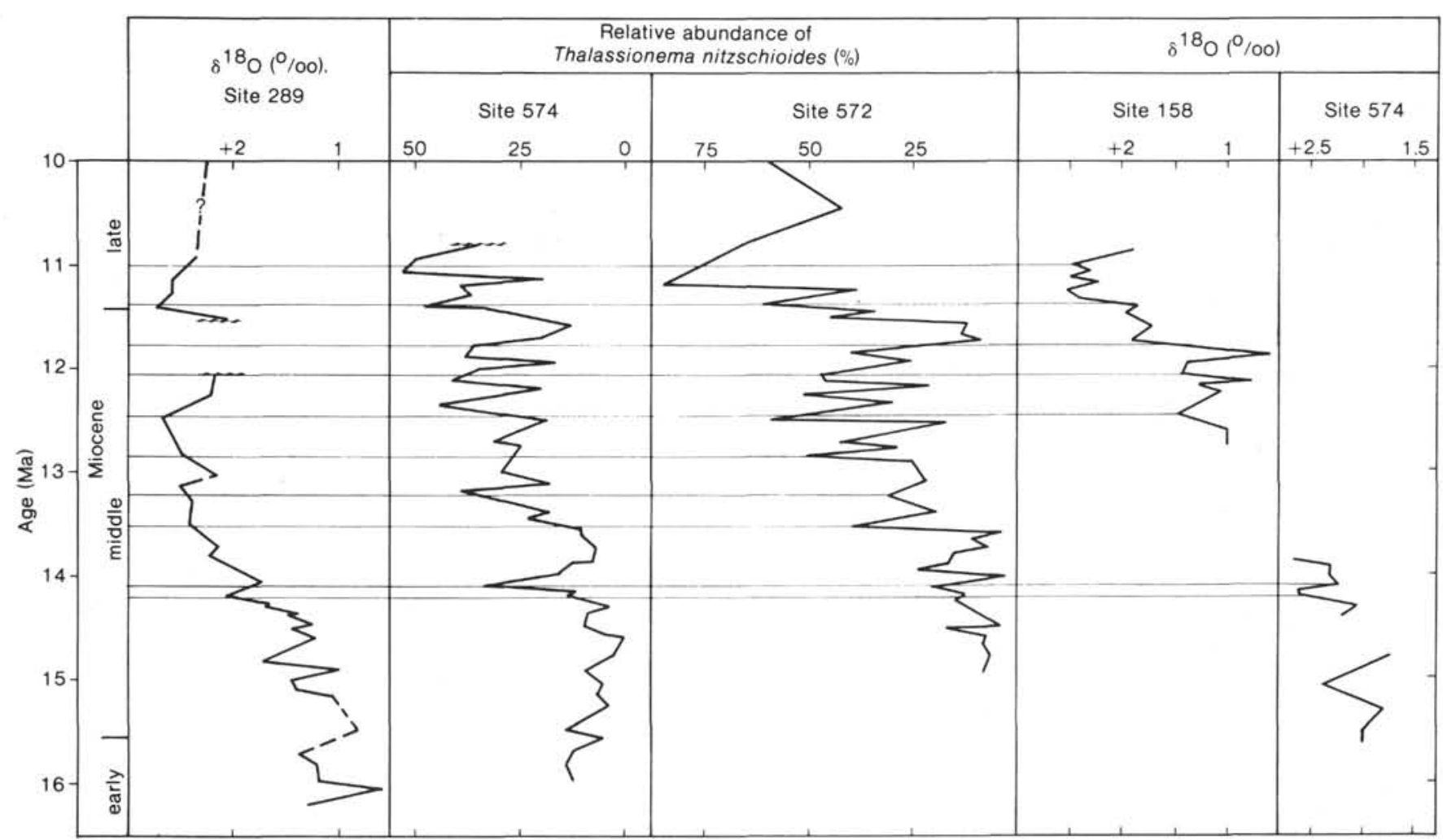

Figure 3. Comparison of the percent of Thalassionema nitzschioides at DSDP Sites 574 and 572 (Barron, this volume) with oxygen-isotope curves for Sites 289 (Woodruff et al., 1981), 158 (Keigwin, 1979), and 574 (Shackleton and Pisias, this volume) for the middle and earliest late Miocene. The Site 574 isotope curve is plotted only from those points that are at the same sub-bottom depth as the Site 574 diatom samples. 
tom samples studied by Barron (this volume). Figure 2 supports the general hypothesis that polar cooling (as reflected by the benthic foraminiferal oxygen-isotope curves) results in a more energetic circulation system and increased upwelling along equatorial divergences in the eastern equatorial Pacific.

On Figure 4, the percent of $T$. nitzschioides at Sites 77 and 572 between 11.5 and $6.2 \mathrm{Ma}$ is plotted and compared with Keller's (in press) late Miocene planktonic foraminiferal climatic curve for Site 289. The sampling interval at Site $\mathbf{5 7 4}$ for the late Miocene is large (typically 500,000 yrs.), so a Site $574 T$. nitzschioides curve was not plotted.

For the late Miocene, Keller (in press) utilizes a ratio of surface-dwelling to intermediate-depth planktonic foraminifers as a measure of relative paleotemperature; higher numbers of intermediate-depth planktonic foraminifers indicate a shallower thermocline and cooling.

Cooling peaks in the $T$. nitzschioides curves at 10.0 , 9.2, 8.8 to $8.7,8.1$ to 7.9 and about $7.1 \mathrm{Ma}$ correlate with cooling peaks in Keller's (in press) planktonic fora- miniferal curve. Between 11.5 and $11.0 \mathrm{Ma}$, the character of the curves differs, but the sampling interval at Site 289 is rather broad and may produce an anomalous curve.

In the middle-latitude northeastern Pacific, Barron and Keller (1983) compared the percentage of cold-water diatoms and planktonic foraminifers in three sections to identify 14 cold peaks and 12 warm peaks during the middle and late Miocene. Late Miocene cold events C8 (11.4 to $11.0 \mathrm{Ma}), \mathrm{C} 9(10.1$ to $9.7 \mathrm{Ma}), \mathrm{C} 10$ (8.8 to 8.7 $\mathrm{Ma}$ ), and $\mathrm{C} 11$ (8.2 to $7.9 \mathrm{Ma}$ ) (ages adjusted to the Leg 85 time scale as described in the Introduction, this volume) show good agreement with the late Miocene cool events identified by abundance peaks of $T$. nitzschioides and Keller's (in press) planktonic foraminiferal curve for Site 289 (Fig. 4). Cold event C12 (6.3 to 6.1 Ma) is not readily apparent in the tropical paleotemperature curves. According to the arguments presented by Barron (1982), cooling periods of the California Current should coincide with periods of increased equatorial upwelling (or intensification of the Peru-Chile Current). These arguments assume that the energy of the whole surfare-

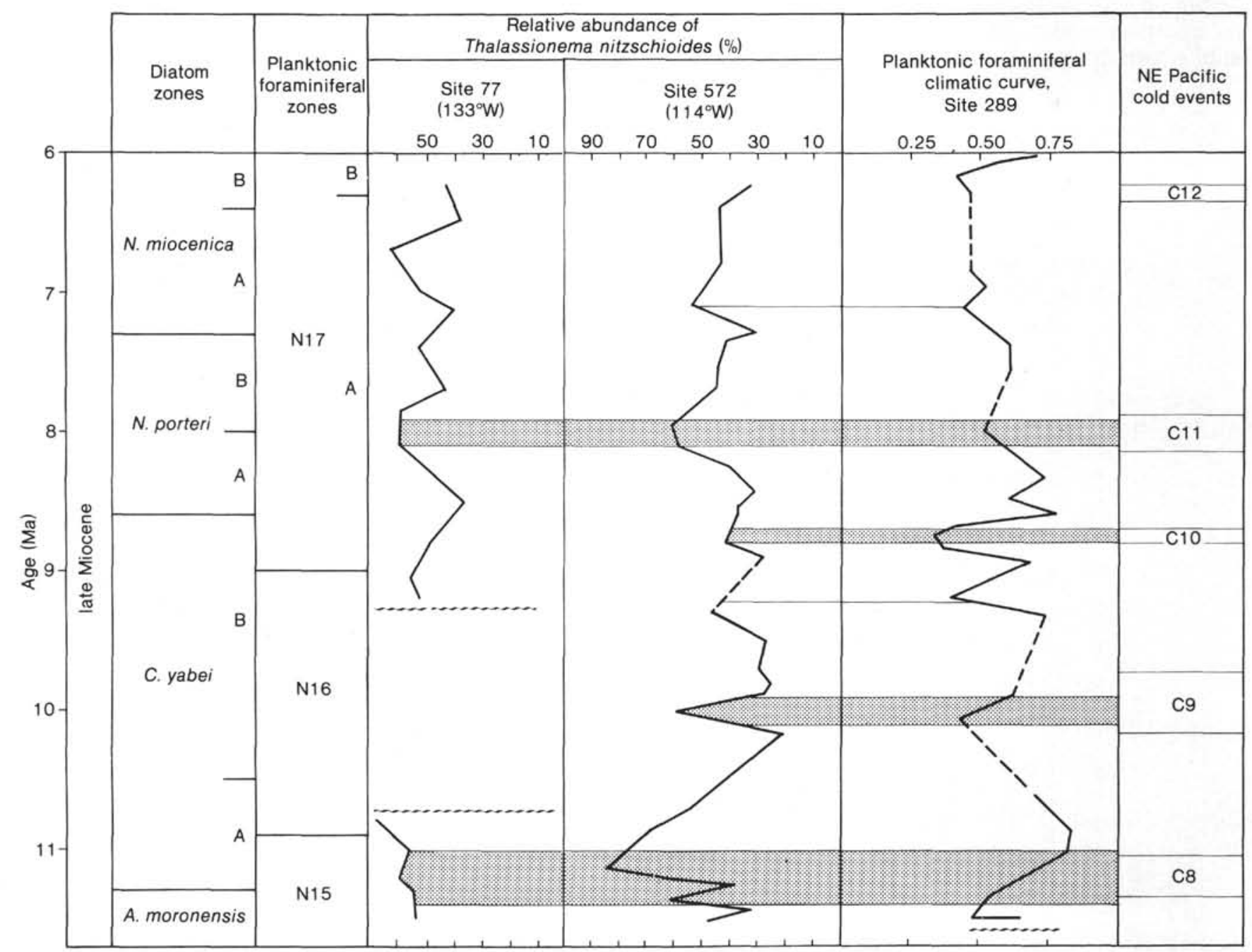

Figure 4. Comparison of the percent of Thalassionema nitzschioides at DSDP Sites 77 and 574 (Barron, this volume) with the planktonic foraminiferal climatic curve of Keller (in press) for Site 289 (see text) and the cold events of Barron and Keller (1983) (northeastern Pacific) for the late Miocene before $6 \mathrm{Ma}$ (see text). Shaded areas show correlation between cold events, cooler values in the planktonic foraminiferal climatic curve, and increased abundance of $T$. nitzschioides. 
water circulation system is enhanced during times of expanded polar glaciation.

\section{Middle Miocene Pulses of Cold-Water Diatoms}

Cold-water diatoms (Denticulopsis hustedtii, D. praedimorpha, Actinocyclus ingens, and Coscinodiscus marginatus) are common in the middle Miocene of the central and eastern equatorial Pacific (Fig. 5); by the 11-Ma level, however, they are essentially absent from low-latitude assemblages. Presence of these dominantly middleto high-latitude diatoms at low latitudes suggests a relatively free exchange of surface water masses between middle and low latitudes. The rapid decline of $D$. hustedtii in the tropical Pacific between 11.5 and 11.3 Ma represents the onset of paleoceanographic isolation between middle- and low-latitude diatom assemblages that typifies the late Miocene (Burckle, 1978; Barron, 1981a). Presumably, conditions in the eastern equatorial Pacific changed at about $11.3 \mathrm{Ma}$ so that dominantly cold-water diatoms could no longer live in the equatorial Pacific. It can be assumed, however, that below the 11.3-Ma level the percentage of cold-water diatoms in tropical middle Miocene assemblages is a measure of the strength of the eastern boundary currents that would carry these middle-latitude diatoms into the tropics. Consequently, peaks in the abundance of cold-water diatoms on Figure 5 should correspond to cooling of equatorial surface waters during the middle Miocene.

Keller (in press) showed that surface-dwelling planktonic foraminifers displayed a strong east-west provincialism in the equatorial Pacific during the early and middle Miocene. She grouped surface-dwelling foraminifers into eastern and western faunas, and argued that the ratio of eastern to western faunal abundance at a given equatorial site reflects surface-water paleotemperatures. The ratio of western fauna to total eastern and western fauna at western equatorial Pacific Site 289 was proposed by Keller (in press) as the basis of a paleotemperature curve for the early and middle Miocene of the western Pacific. She showed that individual cooling spikes (decreases in relative abundance of the western fauna) correlated with cooling peaks in the benthic foraminiferal isotope curve for Site 289.

Comparison of Keller's (in press) curve with the abundance curves for cold-water diatoms at Sites 572 and 574 (Fig. 5) reveals a relatively good correlation of cooling peaks between 16 and 13 Ma but poor correlation between 13 and $12 \mathrm{Ma}$. Keller's (in press) cooling peak at 15.5 Ma corresponds to the introduction of Actinocyclus ingens into the tropics from middle latitudes (Bar-

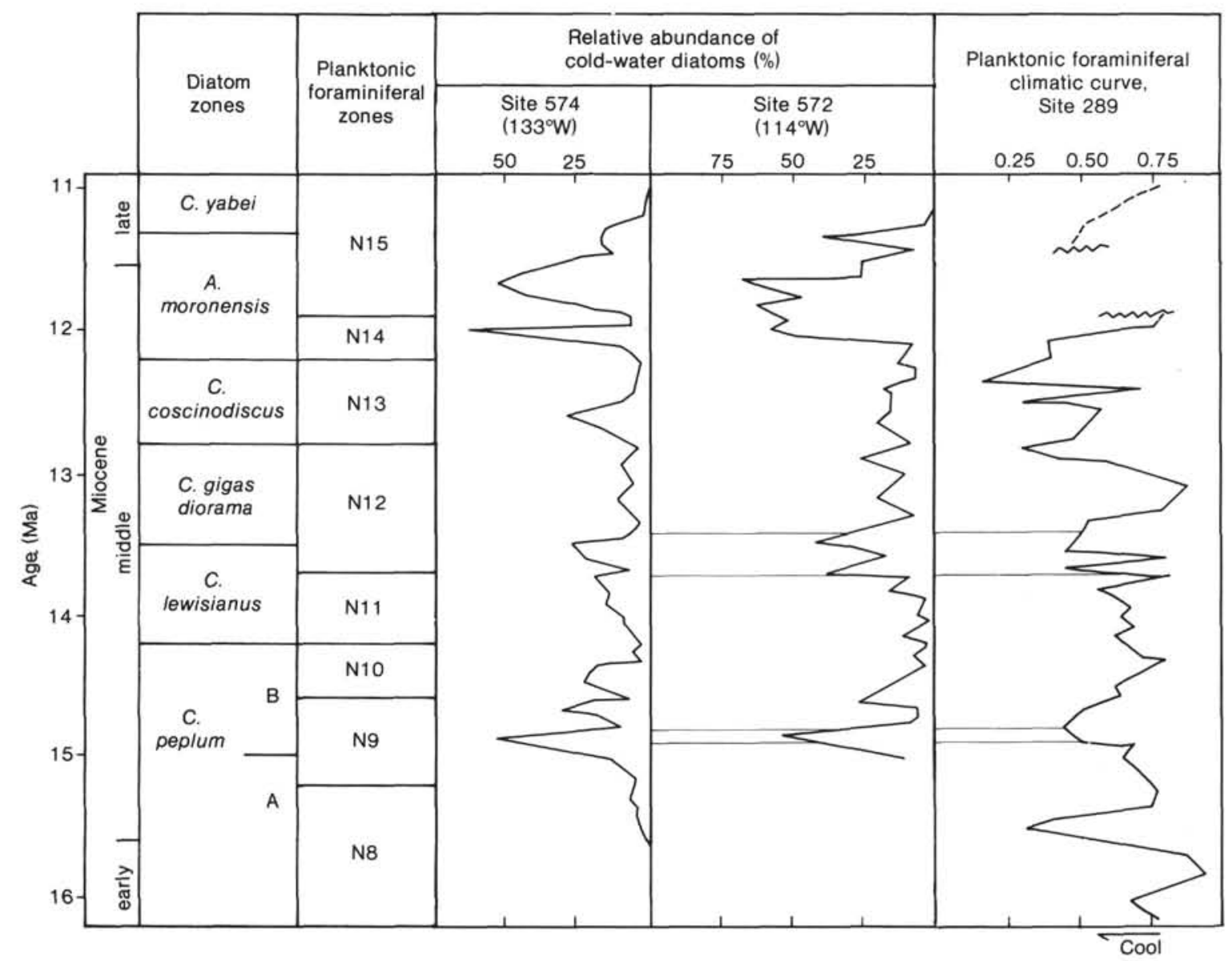

Figure 5. Comparison of the percent of cold-water diatoms (Denticulopsis hustedtii, D. praedimorpha, Actinocyclus ingens, and Coscinodiscus marginatus) in the middle Miocene of DSDP Sites 574 and 572 with the planktonic foraminiferal climatic curve of Keller (in press) at Site 289 (see text). 
ron, this volume). Cooling from 14.9 to $14.8 \mathrm{Ma}$ and from 13.7 to $13.4 \mathrm{Ma}$ is also apparent in both types of curves. Cooling in the Site 289 curve at 12.8 and 12.4 $\mathrm{Ma}$, however, is not apparent in the curves of percent cold-water diatoms, although Figure 3 (percent Thalassionema nitzschioides) does indicate increased upwelling (or intensification of the Peru-Chile Current) at 12.8 and $12.5 \mathrm{Ma}$.

The large increase in the abundance of Denticulopsis hustedtii between 12 and 11.5 Ma (Fig. 6) corresponds to hiatus $\mathrm{NH} 4$ at Site 289 , and coincides with generalized carbonate dissolution throughout the tropics in lower planktonic foraminiferal Zone N15 (Keller, 1981), so comparisons of the two types of curves between 12.0 and 11.5 Ma are not possible. All three paleotemperature curves of Figure 6, however, show warming between 11.5 and $11.0 \mathrm{Ma}$.

The dramatic increases in the abundance of $D . h u$ stedtii from $5-10 \%$ to $50-60 \%$ of the assemblage at $12.0 \mathrm{Ma}$ at Sites 158,572 , and 574 correlates closely with a sharp drop in the percent carbonate at all three sites (Figs. 6, 7). Earlier increases of $D$. hustedtii in the middle Miocene also appear to coincide with carbonate lows at Sites 572 and 574 (Fig. 6). Coincidence of $D$. hustedtii abundance peaks with middle Miocene carbonate-dissolution troughs lends support to arguments that tie polar cooling (benthic foraminiferal oxygen-isotope enrichment) to carbonate dissolution (Dunn et al., 1981; Vincent, 1981). Pedersen (1983) showed that productivity was increased in the eastern equatorial Pacific during the last glacial maximum. Emerson and Bender (1981) argue that increased rain of organic carbon to the seafloor, such as would occur during periods of greater productivity, would result in higher $\mathrm{CO}_{2}$ levels in bottom waters and would stimulate carbonate dissolution there. Berger and Vincent (1981) point out that periods of global cooling and sea-level regression should also release trapped organic carbon to the ocean system by erosion of transient nearshore carbon reservoirs. Consequently, Figures 6 and 7 support arguments-by Keller (1980), Dunn et al. (1981), Vincent (1981), and Barron and Keller (1982)-suggesting that late middle Miocene and late Miocene periods of carbonate dissolution in the Pacific coincided with periods of expanded Antarctic glaciation.

Denticulopsis hustedtii is a dominantly middle- to highlatitude diatom common in the middle and late Miocene of the North Pacific (Koizumi, 1973; Barron, 1980; Barron and Keller, 1983), North Atlantic (Baldauf, 1985), and Southern Ocean (Schrader, 1976; Weaver and Gombos, 1981; Ciesielski, 1983). It was most likely associated with cool, low-salinity water masses that are typical of those regions. Introduction of $D$. hustedtii into the tropical Pacific at 13.9 Ma (Burckle, 1978; Barron, this volume) corresponds to increased positive values of $\delta^{18} \mathrm{O}$ in the benthic foraminiferal oxygen-isotope curves for Sites 289 (Woodruff et al., 1981) and 574 (Shackleton and Pisias, this volume), and also coincides with an increase in the abundance of $D$. hustedtii in the middlelatitude northeastern Pacific (Barron and Keller, 1983). Benthic foraminiferal oxygen-isotope enrichment of about $+0.5 \%$ at $11.7 \mathrm{Ma}$ at Site 158 slightly lags behind the increases in D. hustedtii abundance at $12.0 \mathrm{Ma}$ (Fig. 7).

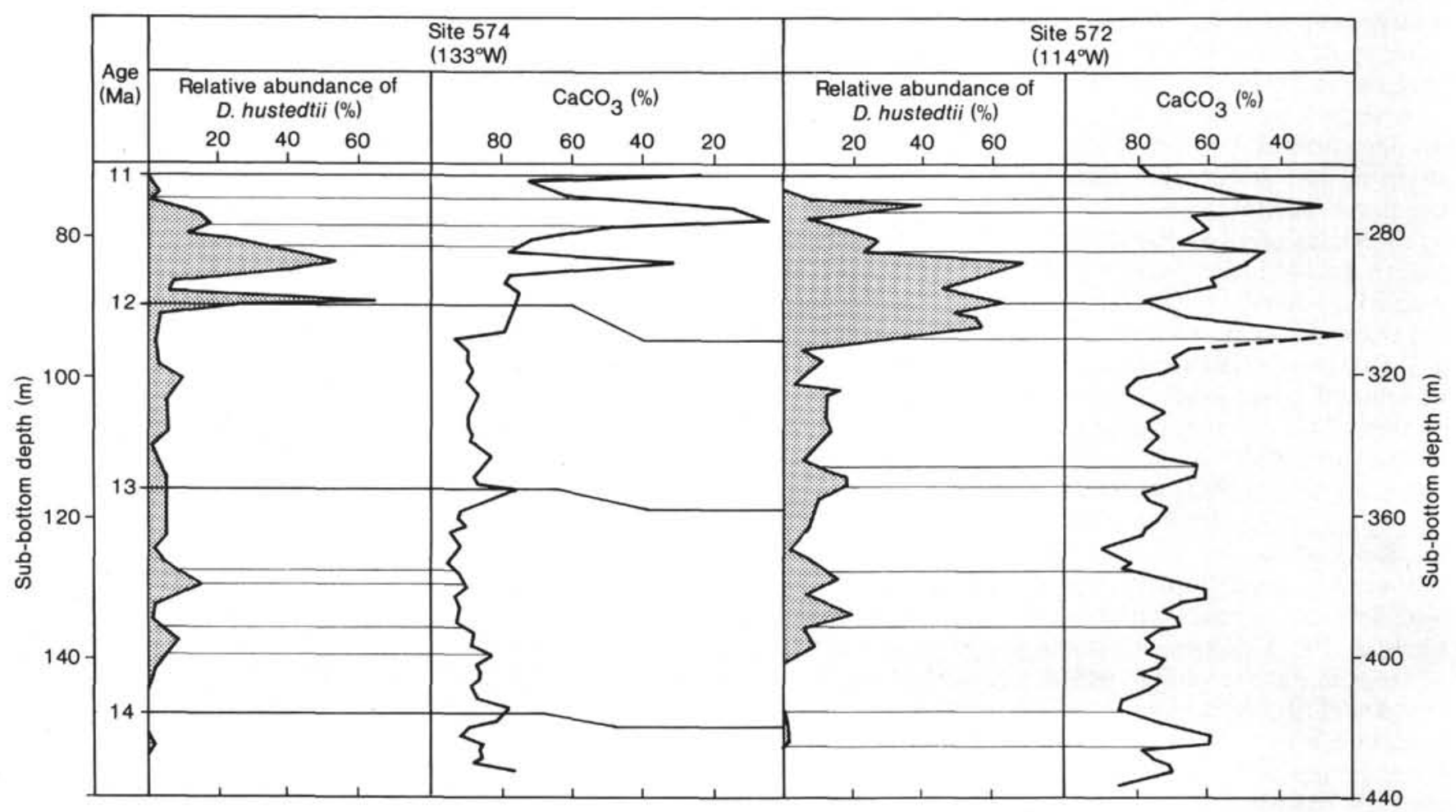

Figure 6. Percentage of the diatom Denticulopsis hustedtii plotted against the percent calcium carbonate (Pisias and Dunn, this volume) for DSDP Sites 574 and 572. 


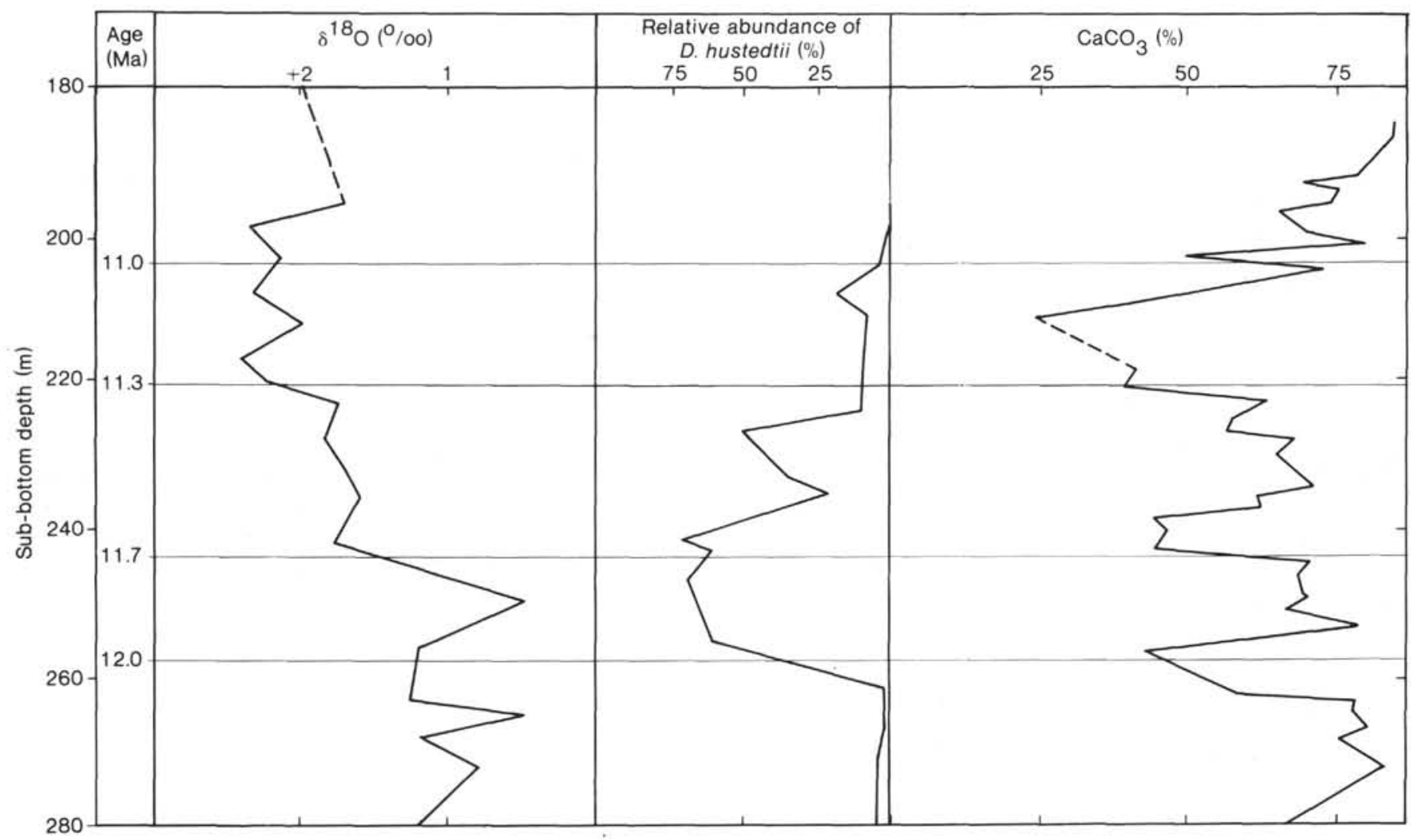

Figure 7. Comparison of the benthic foraminiferal oxygen-isotope record (Keigwin, 1979), the relative abundance of Denticulopsis hustedtii (Barron, this volume), and the percent calcium carbonate (Bode and Cronan, 1973) between 280 and $180 \mathrm{~m}$ sub-bottom depth at eastern equatorial Pacific Site 158. Ages from Barron (this volume).

Keigwin's (1979) sampling interval for isotopes, however, is large, and he notes problems with diagenesis at these lower levels at Site 158, so it is possible that oxygen-isotope values do increase briefly at the $12.0-\mathrm{Ma}$ level.

A second increase of $+0.5 \%$ in the Site 158 oxygenisotope curve at $11.3 \mathrm{Ma}$ interestingly corresponds to a sharp decline in the abundance of $D$. hustedtii in the equatorial Pacific (Figs. 6, 7). This decline was followed by the exclusion of $D$. hustedtii from the equatorial $\mathrm{Pa}$ cific by $11.0 \mathrm{Ma}$ (Barron, this volume). D. hustedtii, however, continued to thrive in the North Pacific and Southern Ocean (Barron and Keller, 1983; Ciesielski, 1983) for at least 2 m.y. after its exclusion from the tropics. Clearly, something happened in the eastern equatorial Pacific at about $11.3 \mathrm{Ma}$ that ended the ability of $D$. hustedtii to live successfully in the tropics.

Savin et al. (1983) have shown, by oxygen-isotope studies on planktonic foraminifers from throughout the tropical Pacific, that polar cooling in the late Miocene was accompanied by warming of tropical surface waters. The calcareous nannofossil data of Lohmann and Carlson (1981) also suggest that a pronounced warming of tropical Pacific surface waters occurred at about 11 Ma. Keller (in press) notes that western equatorial Pacific surface-water assemblages of planktonic foraminifers (Globigerinoides) expanded into the eastern Pacific in the early late Miocene. Presumably, warming of tropical surface waters, coupled with high-latitude cooling at about $11 \mathrm{Ma}$, was responsible for the pronounced in- creases in provincialism - between middle- and low-latitude planktonic foraminifers (Ingle, 1973; Keller, 1981; Srinivasan and Kennett, 1981), calcareous nannofossils (Haq, 1980; Bukry, 1981b), silicoflagellates (Bukry, 1981a), and diatoms (Burckle, 1978; Keller and Barron, 1981)-that occurred in the early late Miocene.

Keller (in press) and Leinen (1979) both argue that the Equatorial Undercurrent intensified in the earliest late Miocene. Leinen (1979) reports that opal accumulation rates along the equator became markedly higher at the eastern end of the Pacific in the early late Miocene, presumably reflecting increased upwelling associated with the Equatorial Undercurrent.

Upwelling of nutrients in the present-day eastern equatorial Pacific results from surface divergences in the South Equatorial Current (Pak and Zaneveld, 1974) and vertical mixing associated with the Equatorial Undercurrent (Jones, 1973). Wyrtki (1966) stresses that the Equatorial Undercurrent drives the South Equatorial Current in the equatorial Pacific, both through diffusion of cool waters upward above the core of the undercurrent and through major input into the eastern end of the South Equatorial Current in the vicinity of the Galapagos Islands, where the undercurrent surfaces. Wyrtki (1966) states that the Peru-Chile Current alone is not strong enough to supply the relatively high velocities of the South Equatorial Current.

Leinen (1979) notes that present-day productivity in the equatorial Pacific is highest southwest of the Gala- 
pagos Islands, where upwelling is intensified by surfacing of the Equatorial Undercurrent, and she argues that changes in the strength and amount of vertical mixing in the Equatorial Undercurrent could cause major changes in biologic productivity in the eastern equatorial Pacific.

Keller's (in press) argument that the Equatorial Undercurrent intensified in the earliest late Miocene hinges on the expansion at that time of intermediate-depth planktonic foraminifers (mostly Globorotalia menardii) at the expense of the surface-dwelling foraminifers, and on the breakdown of the east-west provincialism of surfacedwelling planktonic foraminifers that had typified the early and middle Miocene.

If the Equatorial Undercurrent was intensified at about 11.3 Ma, it may have raised surface-water salinities or altered other water-mass properties enough in the eastern equatorial Pacific to create an effective barrier to the dispersal of $D$. hustedtii and other middle-latitude diatoms into the tropics after $11 \mathrm{Ma}$. Warming of tropical Pacific surface waters may have also resulted if the equatorial countercurrents were also intensified. The increased abundance of Thalassionema nitzschioides from 11.3 to $11.0 \mathrm{Ma}$ (Fig. 4), which occurred in the eastern equatorial Pacific immediately after the decline of $D$. hustedtii, may have reflected increased productivity associated with the Equatorial Undercurrent, as suggested by Leinen (1979), rather than intensification of the PeruChile Current, as suggested by Burckle et al. (1982).

\section{INITIATION OF MIDDLE/LATE MIOCENE CHANGES}

Blanc and Duplessy (1982) argue that North Atlantic Deep Water (NADW) was initiated in the latest middle Miocene (Catinaster coalitus Zone $=[\mathrm{CN} 6]$ of calcareous nannofossils), owing to subsidence of the ScotlandFaroe-Iceland-Greenland Ridge. According to the Leg 85 time scale (Introduction, this volume), this event would have an approximate age of $12.0 \mathrm{Ma}$. Miller and Fairbanks (1983) believe, however, that NADW was initiated in the earliest Oligocene. Keller and Barron (1983) suggest that this event of 12 Ma represented a significant increase in the production of NADW rather than its initiation. In either case, increased production of NADW would have caused major changes in circulation and sedimentation in both the Atlantic and Pacific oceans. Keller and Barron (1983) show that siliceous sedimentation decreased at this time in the middle-latitude North Atlantic and increased in the North Pacific, presumably because expansion of NADW into the North Atlantic would have hindered the upward diffusion of silica-rich Antarctic Bottom Water (AABW) there and increased the amount of silica available elsewhere. Similarly, Isaacs (in press) notes a significant increase in opal accumulation rates in the Monterey Formation of California beginning about $11.5 \mathrm{Ma}$.

Increased production of NADW would increase the flow of warm, saline water into the Antarctic through upwelling of NADW at the Antarctic Divergence. Southward flow of warm, saline water into the modern Weddell Sea brings to the Antarctic moisture, which, in turn, is precipitated and maintains the Antarctic Ice Cap.
Thus, initiation or increased NADW production at 12 Ma would have resulted in expansion of Antarctic glaciation, and would have led to increased production of AABW (Schnitker, 1980).

Increased production of AABW at $12 \mathrm{Ma}$ is reflected by the widespread nature of hiatus NH4 (12 to $11 \mathrm{Ma}$ ) of Keller and Barron (1983) in the world ocean. This hiatus coincides with three pronounced carbonate lows during paleomagnetic Chron 11 and lower Chron 10 throughout the equatorial Pacific (Barron et al., in press; Vincent, 1981; Fig. 7 of this chapter), as was pointed out by Barron and Keller (1982). Indeed, the sediment record of the late Miocene is characterized by numerous widespread deep-sea hiatuses (Keller and Barron, 1983), pronounced intervals of carbonate dissolution alternating with intervals of higher carbonate values (Dunn et al., 1981), and benthic foraminiferal oxygen-isotope values that are enriched positively compared with those of the middle Miocene (Woodruff et al., 1981).

Two enrichment events, each recording about $+0.5 \%$ in benthic foraminiferal oxygen isotopes at DSDP Site 158 (Keigwin, 1979), followed closely after the event of $12 \mathrm{Ma}$. The latter of these two events, at $11.3 \mathrm{Ma}$, may have resulted in intensification of the strength of the Equatorial Undercurrent and the evolution of a late Miocene circulation system characterized by isolation of middle- and low-latitude planktonic microfossil assemblages and steep latitudinal thermal gradients.

\section{SUMMARY}

Three different types of relative paleotemperature curves have been proposed to represent the equatorial Pacific between 18 and $6.2 \mathrm{Ma}$. From 18 to $13.5 \mathrm{Ma}$, the abundance curves of Denticulopsis nicobarica at central equatorial Pacific Sites 574 and 575 reflect the strength of surface-water circulation, with increasing numbers of D. nicobarica being displaced westward from the cooler eastern Pacific during times of polar cooling. At 13.5 Ma, $D$. nicobarica declines abruptly immediately before its extinction at 13.2 Ma. At about the same time, Thalassionema nitzschioides, presently associated with the Peru-Chile Current, becomes imporiant ( $>15 \%$ of the assemblage) in the equatorial Pacific. During periods of polar cooling in the late middle and late Miocene, increases in the abundance of $T$. nitzschioides in the central equatorial Pacific resulted from increases in upwelling and/or intensification of the strength (or flow) of the Peru-Chile Current. Abundant cold-water diatoms in middle Miocene equatorial Pacific sediments suggest an open communication between middle- and low-latitude surface-water diatom assemblages. The abundance curves of cold-water diatoms at Sites 572 and 574 record equatorial surface-water cooling more extreme than that responsible for increases in T. nitzschioides. From 11.3 to $11.0 \mathrm{Ma}$, increased polar cooling was accompanied by a steepening of latitudinal thermal gradients that strengthened provinciality; tropical surface waters apparently became warmer, and cold-water diatoms were excluded from the tropics.

A possible sequence of events accounting for the marked changes in sedimentation and floral and faunal 
distribution across the middle/late Miocene boundary can be summarized as follows. Subsidence of the Scotland-Faroe-Iceland-Greenland Ridge at $12.0 \mathrm{Ma}$ allowed an increased volume of Norwegian Overflow water to mix with saline waters from the North Atlantic Drift, and significantly increased the production of NADW. This change enhanced differences in water-mass formation and circulation between the Atlantic and $\mathrm{Pa}$ cific (Berger, 1970), and caused a decline in siliceous sedimentation in the middle-latitude North Atlantic and a corresponding increase in the Pacific (Keller and Barron, 1983). At the same time, introduction of relatively warm, saline NADW to the Antarctic increased precipitation in the Antarctic and caused expanded glaciation. Production of AABW was enhanced by increased ice in contact with the ocean, which resulted in carbonate dissolution and the widespread hiatus NH4 which characterizes the period between 12 and $11 \mathrm{Ma}$ (Barron and Keller, 1982). The global circulation system was thus made more energetic and the eastern equatorial Pacific cooled, as reflected by pronounced increases in the abundance of the cool-water diatom Denticulopsis hustedtii between 12 and $11.5 \mathrm{Ma}$. The greater amounts of organic carbon that reached the seafloor-consequent either to increased upwelling and productivity or to erosion of transient nearshore carbon reservoirs, caused by sea-level regression-led to higher $\mathrm{CO}_{2}$ levels in bottom water and increased carbonate dissolution. Further polar cooling at about $11.3 \mathrm{Ma}$ caused a further acceleration of the global circulation system, greatly increasing the strength of the Equatorial Undercurrent. Tropical surface waters warmed, possibly because the equatorial countercurrents were also strengthened; high-latitude waters became cooler, and tropical surface-water planktonic assemblages became ecologically isolated from middlelatitude assemblages. Between 11.3 and 6.2 Ma, equatorial Pacific oceanographic conditions were more stable and less variable than during the late middle Miocene. Periods of middle-latitude cooling and intensification of eastern boundary currents appear to coincide with increased upwelling in the central equatorial Pacific.

\section{ACKNOWLEDGMENTS}

I thank the Leg 85 Co-Chiefs, Larry Mayer and Fritz Theyer, and the entire staff for making Leg 85 rewarding and successful. This manuscript was reviewed by Greta Keller, James V. Gardner, and Charles A. Repenning of the U.S. Geological Survey. Jack G. Baldauf, Dean A. Dunn, Lloyd Burckle and David Bukry provided helpful comments. Nick Pisias kindly supplied preliminary copies of carbonate and isotope data. Samples were made available for study by the $\mathrm{Na}-$ tional Science Foundation through the Deep Sea Drilling Project.

\section{REFERENCES}

Baldauf, J. G., 1985. Cenozoic diatom biostratigraphy and paleoceanography of the Rockall Plateau region, North Atlantic, Deep Sea Drilling Project Leg 81. In Roberts, D. G., Schnitker, D., et al., Init. Repts. DSDP, 81: Washington (U.S. Govt. Printing Office), 439-478.

Barron, J. A., 1980. Miocene to Quaternary diatom biostratigraphy of DSDP Leg 57, off northeast Japan. In Scientific Party, Init. Repts. DSDP, 56, 57, Pt. 2: Washington (U.S. Govt. Printing Office), 641-685. 1981a. Late Cenozoic diatom biostratigraphy and paleoceanography of the middle-latitude eastern North Pacific. In Yeats, R. S., Haq, B. U., et al., Init. Repts. DSDP, 63: Washington (U.S. Govt. Printing Office), 507-538.

, 1981b. Middle Miocene diatom biostratigraphy of DSDP Site 77B in the eastern equatorial Pacific. Geosci. J., 2(2):137-144. , 1982. Enhanced late Miocene upwelling in the middle- and low-latitude Pacific. Geol. Soc. Am. Abstr. Progr., 14(17):439. (Abstract)

Barron, J. A., and Keller, G., 1982. Widespread Miocene deep-sea hiatuses: coincidence with periods of global cooling. Geology, 10: $577-581$.

1983. Paleotemperature oscillations in the middle and late Miocene of the northeastern Pacific. Micropaleontology, 29(2): 150-181.

Barron, J. A., Keller, G., and Dunn, D. A., in press. A multiple microfossil biochronology for the Miocene. In Kennett, J. P. (Eds.), The Miocene Ocean: Paleoceanography and Biogeography. Mem. Geol. Soc. Am.

Berger, W. H., 1970. Biogenous deep-sea sediments: fractionation by deep-sea circulation. Geol. Soc. Am. Bull., 81:1385-1402.

Berger, W. H., and Vincent, E., 1981. Chemostratigraphy and biostratigraphic correlations: exercises in systemic stratigraphy. Proc. 26th Int. Geol. Congr., Geol. of Oceans Symp. (Paris, July 7-17, 1980), Oceanol. Acta, No. SP, pp. 115-127.

Blanc, P. L., and Duplessy, J. C., 1982. The deep-water circulation during the Neogene and the impact of the Messinian salinity crisis. Deep Sea Res., 29(12A):1391-1414.

Blow, W. H., 1969. Late middle Eocene to Recent planktonic foraminiferal biostratigraphy. In Brönniman, P., and Renz, H. H. (Eds.), Proc. First Int. Conf. Planktonic Microfossils: Leiden (E. J. Brill), pp. 199-421.

Bode, G. W., and Cronan, D. S., 1973. Carbon and carbonate analyses, Leg 16. In van Andel, T. H., Heath, G. R., et al., Init. Repts. DSDP, 16: Washington (U.S. Govt. Printing Office), 521-528.

Bukry, D., 1978. Biostratigraphy of Cenozoic marine sediment by calcareous nannofossils. Micropaleontology, 24:44-60.

, 1981a. Synthesis of silicoflagellate stratigraphy for Maestrichtian to Quaternary marine sediment. Spec. Publ. Soc. Econ. Paleontol. Mineral., 32:433-444.

1981b. Cenozoic coccoliths from the Deep Sea Drilling Project. Spec. Publ. Soc. Econ. Paleontol. Mineral., 32:335-353.

Bukry, D., and Foster, J. H., 1973. Silicoflagellate and diatom stratigraphy, Leg 16, Deep Sea Drilling Project. In van Andel, T. H., Heath, G. R., et al., Init. Repts. DSDP, 16: Washington (U.S. Govt. Printing Office), 815-871.

Burckle, L. H., 1978. Early Miocene to Pliocene diatom datum levels for the equatorial Pacific. Proc. Second Working Group Meeting, Biostrat. Datum-Planes Pacific Neogene, IGCP Project 114 (Bandung, May 30-June 1, 1977). Spec Publ. Geol. Res. Dev. Ctr., Indonesia, 1:25-44.

Burckle, L. H., Keigwin, L. D., and Opdyke, N. D., 1982. Middle and late Miocene stable isotope stratigraphy: correlation to the paleomagnetic reversal record. Micropaleontology, 25(3):281-293.

Ciesielski, P. F., 1983. The Neogene and Quaternary diatom biostratigraphy of subantarctic sediments, Deep Sea Drilling Project Leg 71. In Ludwig, W. J., Krasheninnikov, V. A., et al., Init. Repts. DSDP, 71: Washington (U.S. Govt. Printing Office), 635-665.

CLIMAP, 1976. The surface of the Ice-Age earth. Science, 191: 1131-1144.

Cooke-Poferl, K., Burckle, L. H., and Riley, S., 1975. Diatom evidence bearing on late Pleistocene climatic changes in the equatorial Pacific. Geol. Soc. Am. Abstr. Progr., 7:1038-1039.

Dunn, D. A., Moore, T. C., Jr., and Keigwin, L. D., Jr., 1981. Atlantic-type carbonate stratigraphy in the late Miocene Pacific. Nature, 291:225-227.

Emerson, S., and Bender, M., 1981. Carbon fluxes at the sedimentwater interface of the deep-sea: calcium carbonate preservation. Mar. Res., 39(1):139-161.

Goll, R. M., 1979. The Neogene evolution of Zygocircus, Neosemantic, and Callimitra: their bearing on nasselarian classification. Micropaleontology, 25(4):365-396. 
Haq, B. U., 1980. Biogeographic history of Miocene calcareous nannoplankton and paleoceanography of the Atlantic Ocean. Micropaleontology, 26(4):414-443.

Ingle, J. C., Jr., 1973. Summary comments on Neogene biostratigraphy, physical stratigraphy, and paleo-oceanography in the marginal northeastern Pacific Ocean. In Klum, L. D., von Huene, R., et al., Init. Repts. DSDP, 18: Washington (U.S. Govt. Printing Office), 949-960.

Isaacs, C. M., in press. Hemipelagic deposits in a Miocene basin, $\mathrm{Cal}$ ifornia: toward a model of lithologic variation and sequence. In Stow, D. A. V., and Piper, D. J. W. (Eds.), Fine-Grained Sediments: Deep-Water Processes and Environments. Spec. Publ. Geol. Soc. London.

Jones, J. H., 1973. Vertical mixing in the Equatorial Undercurrent. $J$. Phys. Oceanogr., 3(3):286-296.

Kanaya, T., and Koizumi, I., 1966. Interpretations of diatom thanatocoenoses from the North Pacific applied to a study of Core V20-130. Tohoku Univ. Sci. Rept., Ser. 2, 37(2):89-130.

Keigwin, L. D., Jr., 1979. Late Cenozoic stable isotope stratigraphy and paleoceanography of DSDP sites from the east equatorial and central North Pacific. Earth Planet. Sci. Lett., 45:361-382.

Keller, G., 1980. Middle to late Miocene planktonic foraminiferal datum levels and paleoceanography of the North and southeastern Pacific Ocean. Mar. Micropaleontol., 5:249-281.

1981. Miocene biochronology and paleoceanography of the North Pacific. Mar. Micropaleontol., 6:535-551. , in press. Depth stratification of planktonic foraminifers in the Miocene ocean: paleoceanographic and paleoclimatic implications. Part II. In Kennett, J. P. (Ed.), The Miocene Ocean: Paleoceanography and Biogeography. Mem. Geol. Soc. Am.

Keller, G., and Barron, J. A., 1981. Integrated planktic foraminiferal and diatom biochronology for the northeast Pacific and the Monterey Formation. In Garrison R. E., et al. (Eds.), The Monterey Formation and Related Siliceous Rocks of California. Spec. Publ. Pacific Sec., Soc. Econ. Paleontol. Mineral., pp. 43-54.

1983. Paleoceanographic implications of Miocene deep-sea hiatuses. Geol. Soc. Am. Bull., 94:590-613.

Koizumi, I., 1973. The late Cenozoic diatoms of Sites 183-193, Leg 19. In Creager, J. S., Scholl, D. W., et al., Init. Repts. DSDP, 19: Washington (U.S. Govt. Printing Office), 805-855.

Leinen, M., 1979. Biogenic silica accumulation in the central equatorial Pacific and implications for Cenozoic paleoceanography. Geol. Soc. Am. Bull., 90:1310-1376.

Lohmann, G. P., and Carlson, J. J., 1981. Oceanographic significance of Pacific late Miocene calcareous nannoplankton. Mar. Micropaleontol., 6:553-579.

Martini, E., 1971. Standard Tertiary and Quaternary calcareous nannoplankton zonation. In Farinacci, A. (Ed.), Proc. Second Planktonic Conf:: Rome (Ed. Tecnoscienza), pp. 739-777.

Matthews, R. K., and Poore, R. Z., 1980. Tertiary ${ }^{18} \mathrm{O}$ record and glacioeustatic sea-level fluctuations. Geology, 8:501-504.

Miller, K., and Fairbanks, R. G., 1983. Abyssal circulation in the North Atlantic during the early to middle Miocene. Geol. Soc. Am. Abstr. Progr., 15(4):645. (Abstract)

Pak, H., and Zaneveld, J. R. V., 1974. Equatorial front in the eastern Pacific Ocean. J. Phys. Oceanogr., 4(4):570-578.

Pedersen, T. F., 1983. Increased productivity in the eastern equatorial Pacific during the last glacial maximum $(19,000$ to 14,000 yr. BP). Geology, 11:16-19.
Riedel, W. R., and Sanfilippo, A., 1978. Stratigraphy and evolution of tropical Cenozoic radiolarians. Micropaleontology, 24(1):61-96.

Romine, K., 1982. Late Quaternary history of atmospheric and oceanic circulation in the eastern equatorial Pacific. Mar. Micropaleontol., 7(2):163-187.

Ryan, W. B. F., Cita, N. B., Rawson, M. D., Burckle, L. H., and Saito, T., 1974. A paleomagnetic assignment of Neogene stage boundaries and the development of isochronous datum planes between the Mediterranean, the Pacific, and Indian oceans in order to investigate the response of the world ocean to Mediterranean "salinity crisis." Riv. Ital. Paleontol., 80:631-688.

Sancetta, C., 1983. Biostratigraphic and paleoceanographic events in the eastern equatorial Pacific: results of Deep Sea Drilling Project Leg 69. In Cann, J. R., Langseth, M. G., Honnorez, J., Von Herzen, R. P., White, S. M., et al., Init. Repts. DSDP, 69: Washington (U.S. Govt. Printing Office), 311-342.

Savin, S. M., Barrera, E., Bender, M., Hodell, D., Keller, G., et al., 1983. Three-dimensional temperature evolution of Miocene oceans, as inferred from foraminiferal oxygen isotopes. Geol. Soc. Am. Abstr. Progr., 15(4):678. (Abstract)

Savin, S. M., Douglas, R. G., and Stehli, F. G., 1975. Tertiary marine paleotemperatures. Geol. Soc. Am. Bull., 86:1499-1510.

Schnitker, D., 1980. North Atlantic oceanography as possible cause of Antarctic glaciation and eutrophocation. Nature, 284:615-616.

Schrader, H. J., 1976. Cenozoic planktonic diatom biostratigraphy of the southern Pacific Ocean. In Hollister, C. D., Craddock, C., et al., Init. Repts. DSDP, 35: Washington (U.S. Govt. Printing Office), 605-671.

Shackleton, N. J., and Kennett, J. P., 1975. Paleotemperature history of the Cenozoic and the initiation of Antarctic glaciation: oxygen and carbon isotope analysis in DSDP Sites 277,279 , and 281 . In Kennett, J. P., Houtz, R. E., et al., Init. Repts. DSDP, 29: Washington (U.S. Govt. Printing Office), 743-755.

Srinivasan, M. S., and Kennett, J. P., 1981. Neogene planktonic foraminiferal biostratigraphy and evolution: equatorial to subantarctic South Pacific. Mar. Micropaleontol., 6:499-533.

van Andel, T. H., Heath, G. R., and Moore, T. C., Jr., 1975. Cenozoic history and paleoceanography of the central equatorial Pacific Ocean. Mem. Geol. Soc. Am., 143:1-134.

Vincent, E., 1981. Neogene carbonate stratigraphy of Hess Rise (central North Pacific) and paleoceanographic implications. In Thiede, J., Vallier, T. L., et al., Init. Repts. DSDP, 62: Washington (U.S. Govt. Printing Office), 571-606.

Weaver, F. M., and Gombos, A. M., Jr., 1981. Southern high-latitude diatom biostratigraphy. Spec. Publ. Soc. Econ. Paleontol. Mineral., 32:445-470.

Woodruff, F., and Douglas, R. G., 1981. Response of deep sea benthic foraminifera to Miocene paleoclimatic events, DSDP Site 289. Mar. Micropaleontol., 6:617-632.

Woodruff, F., Savin, S. M., and Douglas, R. G., 1981. Miocene stable isotope record: a detailed deep Pacific Ocean study and its paleoclimatic implications. Science, 212:665-668.

Wyrtki, K., 1966. Oceanography of the eastern equatorial Pacific Ocean. In Barnes, H. (Ed.), Oceanography and Marine Biology, Ann. Rev.: London (George Allen and Unwin Ltd.), 4:33-68.

Date of Initial Receipt: 14 October 1983

Date of Acceptance: 6 March 1984 